\title{
Fish Community Composition, Seasonality and Abundance in Fortaleza Lagoon, Cidreira
}

\author{
Lúcia Cabral Schifino ${ }^{*}$, Clarice Bernhardt Fialho and José Roberto Verani \\ Universidade Federal de São Carlos; C. P. 676; 13565-906; São Carlos - SP - Brazil
}

\begin{abstract}
The Fortaleza Lagoon belongs to the Southern Tramandai subsystem, formed by lagoons disposed linearly on the north-south direction $\left(30^{\circ} 08^{\prime} \mathrm{S}, 50^{\circ} 13^{\prime} \mathrm{W}\right)$. The objective of this study was to describe some aspects related to the composition of the fish community of Fortaleza Lagoon. Samples were collected monthly from November 1998 to October 1999. The specimens were captured at four previously determined points in the lagoon, and classified in five orders, 12 families and 22 species. Cyphocharax voga, Hyphessobrycon luetkenii, Oligosarcus jenynsii, Oligosarcus robustus and Loricariichthys anus were more abund ant species. Amongst the sampled species only two could not be characterised as freshwater species: Centropomus sp (marine) and Lycengraulius grossidens (estuarine). The ichthyofauna of the lagoon was predominantly composed by constant species.
\end{abstract}

Key words: Freshwater fishes, coastal lagoons, Rio Grande do Sul, Brazil

\section{INTRODUCTION}

In the last decade, studies involving fish communities indicate their importance as indicators of environmental quality levels in freshwater systems (Fausch et. al., 1990; Karr, 1991; Bruschi Jr. et al., 1998). Evaluations on fishing stocks or productive potential on tropical and subtropical systems fish communities still have limited approaches. (YáñezArancibia, 1986). According to Böhlke (1978), the South American freshwater fishes are among the least known in the world. The large volume of information that constitute the data for neotropical fish studies could be responsible for the lack of scientific production in this area, specially in lagoons. In South America, approximately $12 \%$ of the coastal zone is formed by lagoon environments. A large number of lagoon ecosystems are found in the Brazilian coast and the highest number of coastal lagoons are situated in the State of Rio Grande do Sul (Esteves et al.,
1984). The coastal plain of Rio Grande do Sul possesses a huge diversity of aquatic environments, formed by lagoons, swamps, channels and the ocean composing together an unique ecosystem with important ecological characteristics. The preservation of this natural system depends on specific environmental research. Studies focusing fish communities in Rio Grande do Sul Lagoons were carried out by Hartz (1997) in Caconde Lagoon, Fialho (1998) in Custódias Lagoon and Bruschi Jr. (1998) in Marcelino and Peixoto Lagoons. The aim of this study is to describe some aspects related to the composition of the fish community of Fortaleza Lagoon: species abundance and occurrence. Fish community studies in lagoons have the scope of increasing the knowledge and understanding of these water corps, envisaging an adequate management of the region considering that these corps have been suffering impacts due to human activities such as

\footnotetext{
Author for correspondence
} 
disordered constructions, domestic garbage and agriculture in the surrounding area.

\section{MATERIALS AND METHODS}

The Fortaleza Lagoon $\left(30^{\circ} 08^{\prime} \mathrm{S}, \quad 50^{\circ} 13 \mathrm{~W}\right)$ is located in Cidreira, in the Southern Tramandaí subsystem between Manuel Nunes Lagoon and Cidreira Lagoon. The Lagoon has an average depth of $1.6 \mathrm{~m}$, an area of $19.06 \mathrm{~km}^{2}$ and a volume of $30.69 \times 10^{6} \mathrm{~m}^{3}$. Salinity measurements and water temperature were taken for each sampling point and revision time. The Lagoon ichthyofauna was sampled monthly during the period from November 1998 to October 1999. Four sampling points were previously defined based on the different biotypes in the lagoon. Points 2 and 3 were located near the lagoons conections with Manuel Nunes lagoon (north) and Cidreira lagoon (south) and both presented marginal vegetation and muddy bottom. Point 1 presented the greatest concentration of marginal vegetation and was situated on the northwest section of the lagoon. Point 4 was located near a sand dune environment on the northeast section with little marginal vegetation and sandy bottom. The specimens were captured by four sets of fishing nets. Each set comprised five nets with distance between knots of $2.0 ; 2.5 ; 3.0 ; 3.5$ and $4.0 \mathrm{~cm}$. Each net had a standard dimension of $1.5 \mathrm{~m}$ in height by $10 \mathrm{~m}$ in length. They were spread out perpendicularly to the margin, starting by the net that presented the smallest distance between knots positioned in the shallowest part of the sampling spot. The nets were always placed in the lagoon at 12 p.m and revised at 18 p.m, 6 am and 12 p.m on the next day when they were then removed. The collected fish samples were separated according to date, collecting spot, net and time, packed in plastic bags and taken to the laboratory where they were kept on the freezer. The estimate of the most abundant species considered the number of individuals collected in $75 \mathrm{~m}^{2}$ of fishing net.

The Constancy of Occurrence was based on the ecological index proposed by Dajoz (1983):

$$
\mathrm{C}=\mathrm{P} / \mathrm{Q} \times 100
$$

where:

$\mathrm{C}=$ Constancy of Occurrence of the species

$\mathrm{P}=$ Number of samples where the species ocurred

$\mathrm{Q}=$ Total number of samples
The species were then divided into three categories:

$$
\begin{array}{ll}
\text { - } & \text { Constants (when } \mathrm{C}>50 \% \text { ) } \\
\text { - } & \text { Acessories (when } 25 \% \leq \mathrm{C} \leq 50 \% \text { ) } \\
\text { - } & \text { Accidental (when } \mathrm{C}<25 \% \text { ) }
\end{array}
$$

The aplication of a Cluster Analysis for sampling spots in high and low temperature periods, based on the $\mathrm{FO} \%$, aimed to investigate the existence of icthyofaunistic similarities between spots in the lagoon using the NTSYSpc $-2.02 \mathrm{~h}$ version (Applied Biostatistics Inc., 1986-1998). The two periods, high and low temperatures were defined according to the distribution of temperatures along the year that suggested two distinctive periods (Fig. 1). The method used for the application of the cluster was the UPGMA (unweighted pair group methodarithmetic averages) (Pielou, 1984; Digby and Kempton, 1987 and Manly, 1994) and the choice of the Bray-Curtis similarity measure (Digby and Kempton, 1987) was based on the cophenetic correlation coefficient values, which indicated that this measure was adequately representing the sampling spots on the cluster. A Factor Analysis extracting the Principal Components (PCA), based on on the $\mathrm{FO} \%$ was also applied to verify the influence of the selected variables on the ordenation of the sampling spots according to high and low temperature periods (Johnson and Wichern, 1998). The software used for PCA was Statistica for Windows 4.2 version (Statsoft Inc., 2000).

\section{RESULTS}

The mean water temperature values for each month and their respective standard deviations during the study period is shown on Table 1 . The cumulative frequency of the fish species collected in Fortaleza Lagoon, presented in Fig. 1, indicated that the number of samples were sufficient for capturing the species susceptible to the fishing artefact used. From the 48 samples collected from November 1998 to October 1999 in the Fortaleza Lagoon, 3325 individuals were captured. They were categorised into 22 species, 12 families and five orders as presented in Table 2 together with the species code and their frequency of occurrence. The categories used followed those proposed by Figueiredo and Menezes $(1978 ; 1980)$ and Malabarba and Isaía (1992). 
Table 1 -Mean Monthly Values of Water Temperature and the Standard Deviation (SD) for the Fortaleza Lagoon during the Study Period.

\begin{tabular}{lcc}
\hline \multicolumn{1}{c}{ Months } & Mean Monthly Water Temperature $\left({ }^{\mathbf{0}} \mathbf{C}\right)$ & DV \\
\hline Nov/98 & 22.59 & 1.00 \\
Dec/98 & 24.93 & 0.73 \\
Jan/99 & 28.38 & 1.50 \\
Feb/99 & 27.39 & 0.78 \\
Mar/99 & 25.53 & 0.94 \\
Apr/99 & 20.51 & 0.81 \\
May/99 & 19.32 & 0.49 \\
Jun/99 & 16.54 & 0.96 \\
Jul/99 & 16.02 & 0.51 \\
Aug/99 & 14.56 & 1.43 \\
Sep/99 & 18.83 & 0.87 \\
Oct/99 & 21.60 & 1.37 \\
\hline
\end{tabular}

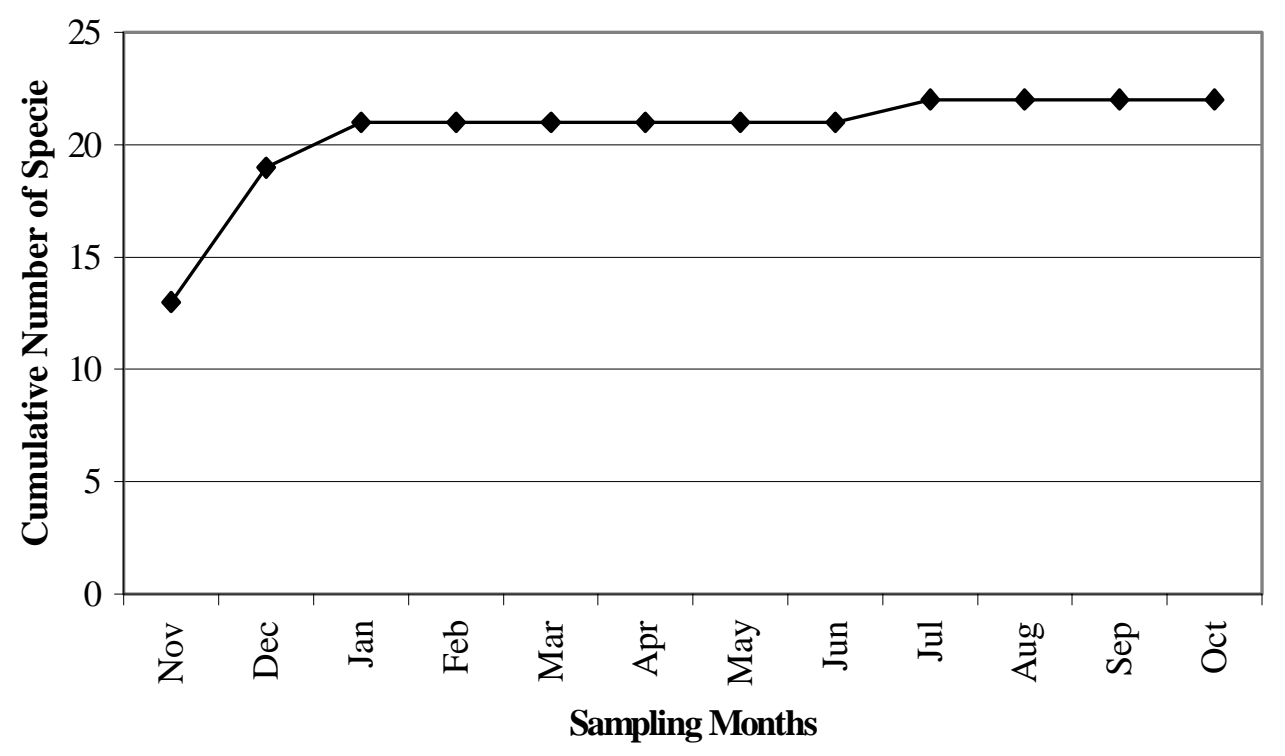

Figure 1 - Relation between the number of samples and the cumulative number of fish species captured in Fortaleza lagoon during November 1998 to October 1999. 
(a)

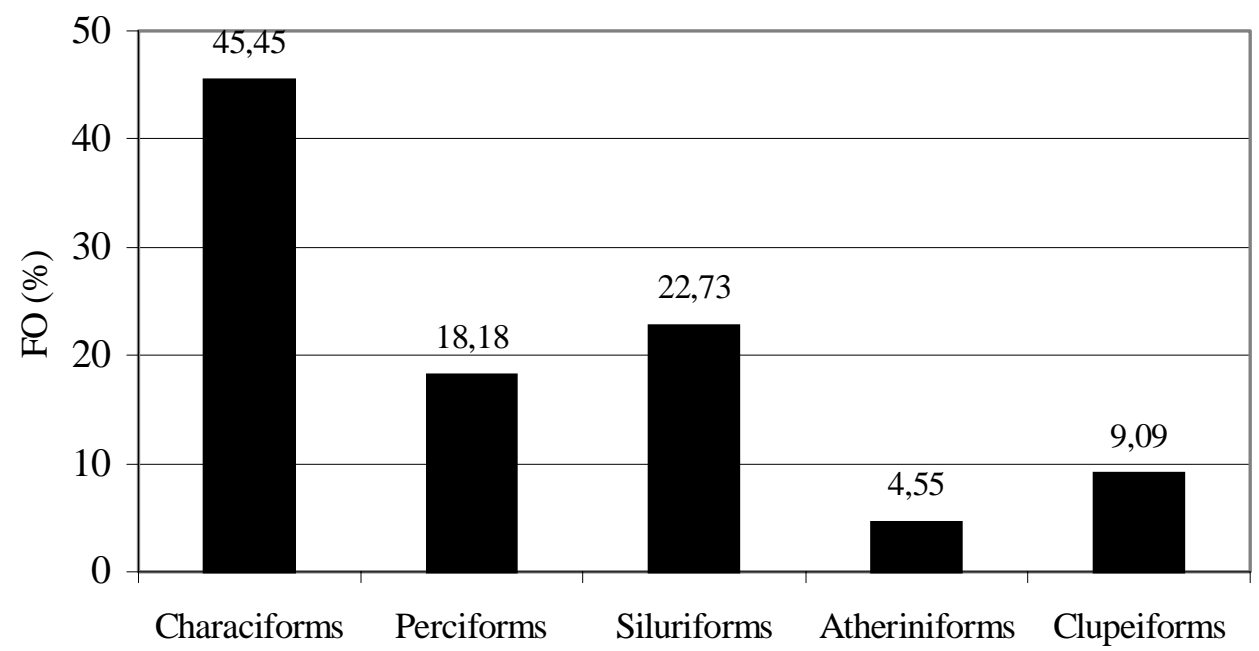

(b)

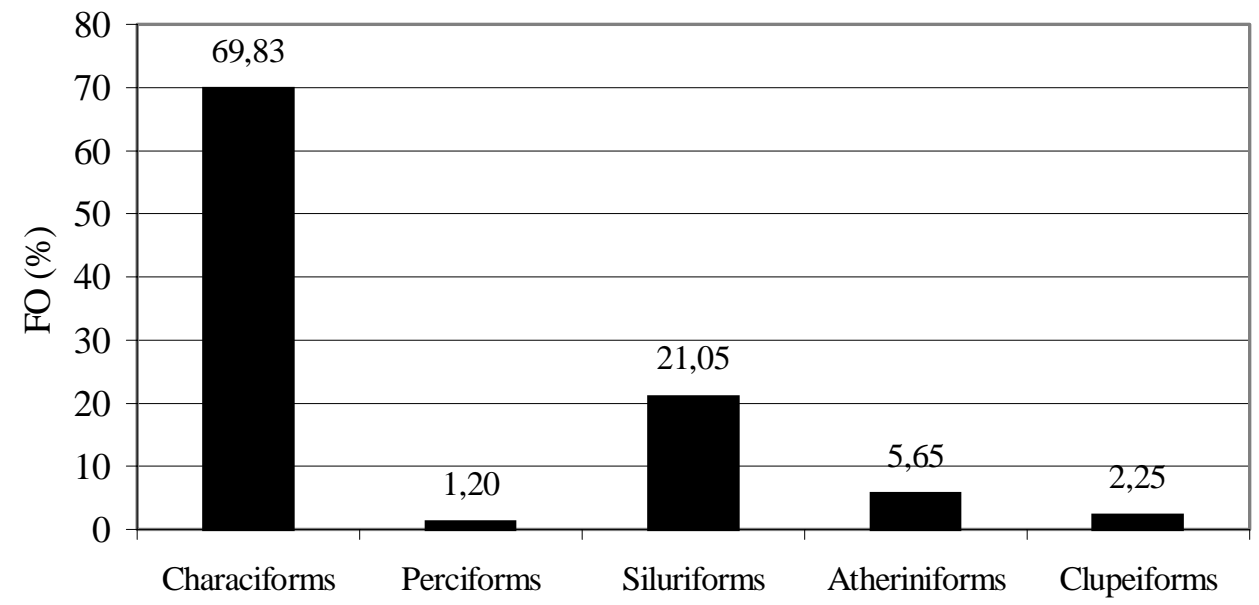

Figure 2 - Frequency of Ocurrence (FO) of the orders considering the number of species (a) and the number of individuals (b) in the Fortaleza Lagoon during the period from November 1998 to October 1999.

The Ordem Characiforms was the most representative, considering the number of species (45\%) and the number of individuals (70\%) (Figs. 2a and 2b).

From the total number of captured individuals, six species represented $87.76 \%$. These were Hyphessobrycon luetkenii (HK), Cyphocharax voga (CV), Oligosarcus jenynsii (OJ), Oligosarcus robustus (OR), Odonthestes sp. (OD) and Loricariichthys anus (LA). Based on the values of frequency of occurrence of species, among the 22 captured species, 13 were considered constant, 6 accessories and 3 accidental ( Table 2). Analysing Table 2 it could be seen that Astyanax fasciatus (AF), Astyanax sp. (ASP), Charax stenopterus (CS), Cyphocharax voga (CV), Geophagus brasiliensis (GB), Hyphessobrycon luetkenii (HK), Hoplias aff. malabaricus (HM), Loricariichthys anus (LA), Lycengraulius grossidens (MJ), Odonthestes sp. (OD), Oligossarcus jenynsii (OJ), 
Oligossarcus robustus (OR) and Trachelyopterus lucenai (PO) were constant; Astyanax aff. bimaculatus (AB), Astyanax eigenmanniorum (AE), Crenicichla punctata (CP), ,Corydora paleatus (JO), Rhamdia aff. quelen (JU) and Rineloricaria quadrensis (RH) considered accessory species, and were, Crenicichla lepidota (CL), Platanichthys platana (PP) and Centropomus sp. (RO) accidental. The relative occurrence of constant, accessory and accidental species was, 59, 27 and 14 , respectively.

The similarity cluster (Figure 3) indicated the presence of two groups based on high and low temperatures, suggesting that the similarity between points was strongly determined by this factor. This tendency was reforced by the PCA analysis shown in Fig. 4 where the first factor account for $71.2 \%$ and the second factor for
$18.8 \%$ of the total variance. On the positive section of the first axe, the most influent variables were Loricariichthys anus (2.72) and Cyphocharax voga (2.22), and were most abundant species along the sampling period (nov/98 to oct/99). The negative section of the first axe did not present significant values. On the second axe, the positive section was strongly influenced by Hyphessobrycon luetkenii (3.21) and Cyphocharax voga (1.58) (the most abundant species in the high temperature period) and the negative section by Loricariichthys anus (-2.46) (the most abundant specie in the low temperature period) This ordenation made possible the interpretation of the first factor as being the abundance of constant species and the second factor as being high and low temperature periods.

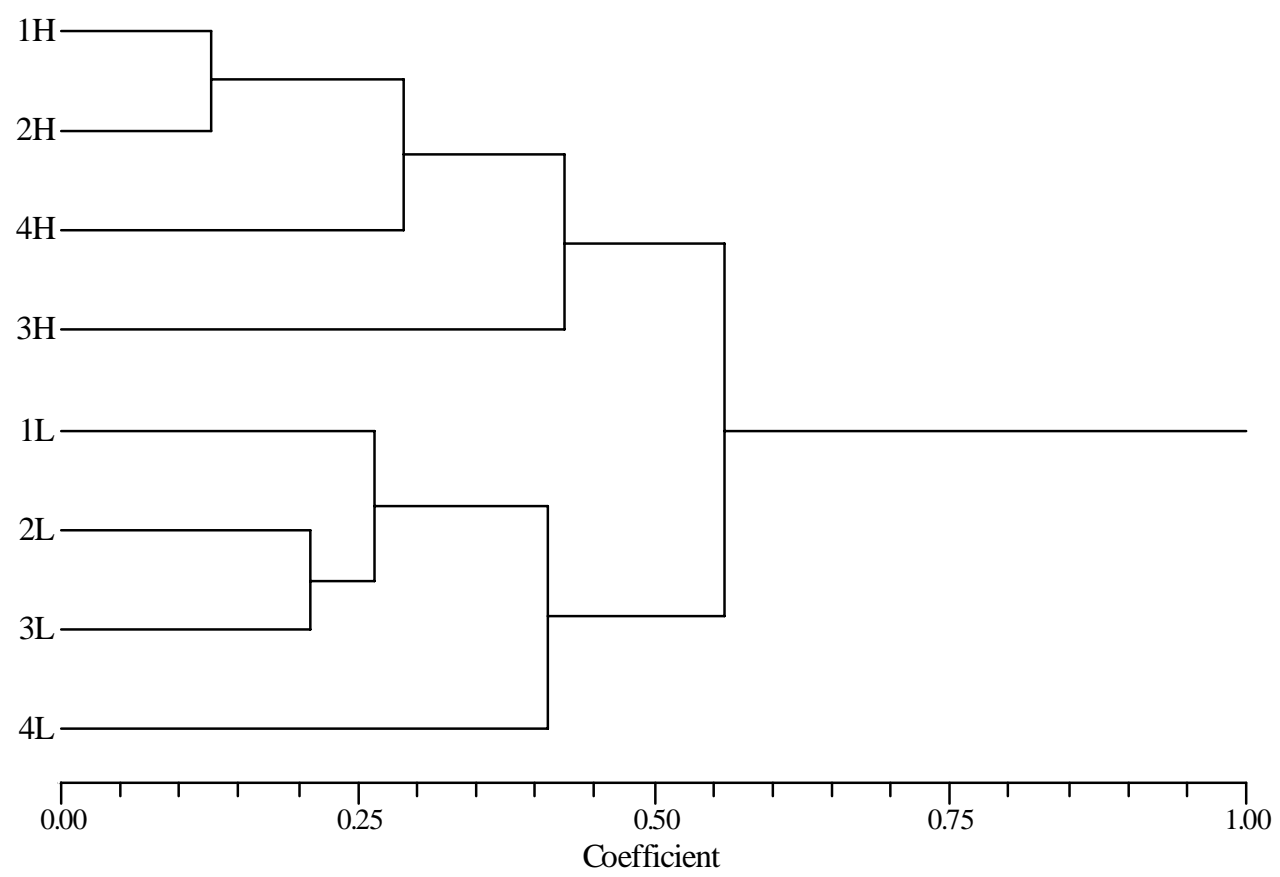

Figure 3 - Cluster using a Bray-Curtis similarity measure for the sampling spots in high $(\mathrm{H})$ and low (L) temperatures for the fish comunity of the Fortaleza lagoon during the period from November 1998 to October 1999. 
Table 2 - Fish species recorded from Fortaleza lagoon, identification codes, number of collected individuals, relative frequency of species, frequency of occurrence and Classification according to Constance of Occurrence during the period from November 1998 to October 1999.

\begin{tabular}{|c|c|c|c|c|c|}
\hline Species & Code & $\begin{array}{c}\mathrm{N}^{0} \text { of } \\
\text { individua } \\
\text { ls }\end{array}$ & $\begin{array}{c}\text { Relative } \\
\text { Frequency } \\
(\%)\end{array}$ & $\begin{array}{c}\text { Frequency of } \\
\text { Occurrence } \\
(\%)\end{array}$ & $\begin{array}{l}\text { Classification } \\
\text { according to } \\
\text { Constance of } \\
\text { Occurrence }\end{array}$ \\
\hline & & & & & $\begin{array}{lll}(1) & (2) & \text { (3) }\end{array}$ \\
\hline
\end{tabular}

\begin{tabular}{|c|c|c|c|c|c|}
\hline \multicolumn{6}{|l|}{$\begin{array}{l}\text { Order: Characiforms } \\
\text { Family: Characidae }\end{array}$} \\
\hline Astyanax aff. bimaculatus (Linnaeus, 1758) & $\mathrm{AB}$ & 21 & 0.63 & 41.67 & \\
\hline Astyanax eigenmanniorum (Cope. 1864) & $\mathrm{AE}$ & 11 & 0.33 & 33.33 & \\
\hline Astyanax fasciatus (Cuvier. 1819) & $\mathrm{AF}$ & 38 & 1.35 & 58.33 & $X$ \\
\hline Astyanax sp. & ASP & 52 & 1.56 & 91.67 & $X$ \\
\hline Charax stenopterus (Cope. 1894) & $\mathrm{CS}$ & 11 & 0.33 & 50.00 & \\
\hline Hyphessobrycon luetkenii (Boulenger. 1887) & HK & 583 & 17.53 & 100.00 & $X$ \\
\hline Oligosarcus jenynsii (Günther. 1864) & $\mathrm{OJ}$ & 328 & 9.86 & 100.00 & $X$ \\
\hline Oligosarcus robustus (Menezes. 1969) & OR & 296 & 8.90 & 100.00 & $X$ \\
\hline \multicolumn{6}{|l|}{ Family: Curimatidae } \\
\hline Cyphocharax voga (Hensel. 1869) & $\mathrm{CV}$ & 883 & 26.56 & 100.00 & $X$ \\
\hline Family: Erythrinidae & & & & & \\
\hline Hoplias aff. malabaricus (Block. 1794) & $\mathrm{HM}$ & 82 & 2.77 & 100.00 & $\boldsymbol{X}$ \\
\hline
\end{tabular}

Order: Perciforms

Family: Cichlidae

Crenicichla lepidota (Heckel. 1840)

Crenicichla punctata (Hensel. 1870)

Geophagus brasiliensis (Quoy and Gaimard.

1824)

Family: Centropomidae

Centropomus sp.

CL
GB

0.06

16.67

25.00

0.12

66.67

\section{$\mathbf{X}$}

$X$

$\boldsymbol{X}$

$33-0.99$

RO 1

0.03

8.33

$\boldsymbol{X}$

Order: Siluriforms

Family: Auchenipteridae

Trachelyopterus lucenai (Bertoletti,

PO

34

1.02

58.33

$\boldsymbol{X}$

Family: Callichthydae

Corydora paleatus (Jenyns. 1842)

Family: Loricariidae

Loricariichthys anus (Valenciennes. 1840)

Rineloricaria quadrensis (Reis. 1983)

Family: Pimelodidae

Rhamdia aff. quelen (Quoy and Gaimard. 1824)

$\begin{array}{lccccc}\text { JO } & 5 & 0.15 & 25.00 & & \boldsymbol{X} \\ \text { LA } & 640 & 19.25 & 100.00 & \boldsymbol{X} & \\ \text { RH } & 18 & 0.54 & 33.33 & & \boldsymbol{X} \\ \text { JU } & 3 & 0.09 & 25.00 & & \boldsymbol{X}\end{array}$

Order: Atheriniforms

Family: Atherinidae

Odontesthes ledae (Malabarba and Dyer,

OD $\quad 188$

5.65

100.00

$\boldsymbol{X}$ 2001)

Order: Clupeiforms

Family: Clupeidae

Platanichthys platana (Regan. 1917)

Family: Engraulidae

Lycengraulius grossidens (Agassiz.

$\begin{array}{cc}\text { PP } & 4 \\ \text { MJ } & 71\end{array}$

0.12

16.67

$\boldsymbol{X}$ 1829)

(1)Constant species, (2) Accessorie specie, (3) Accidental Specie 


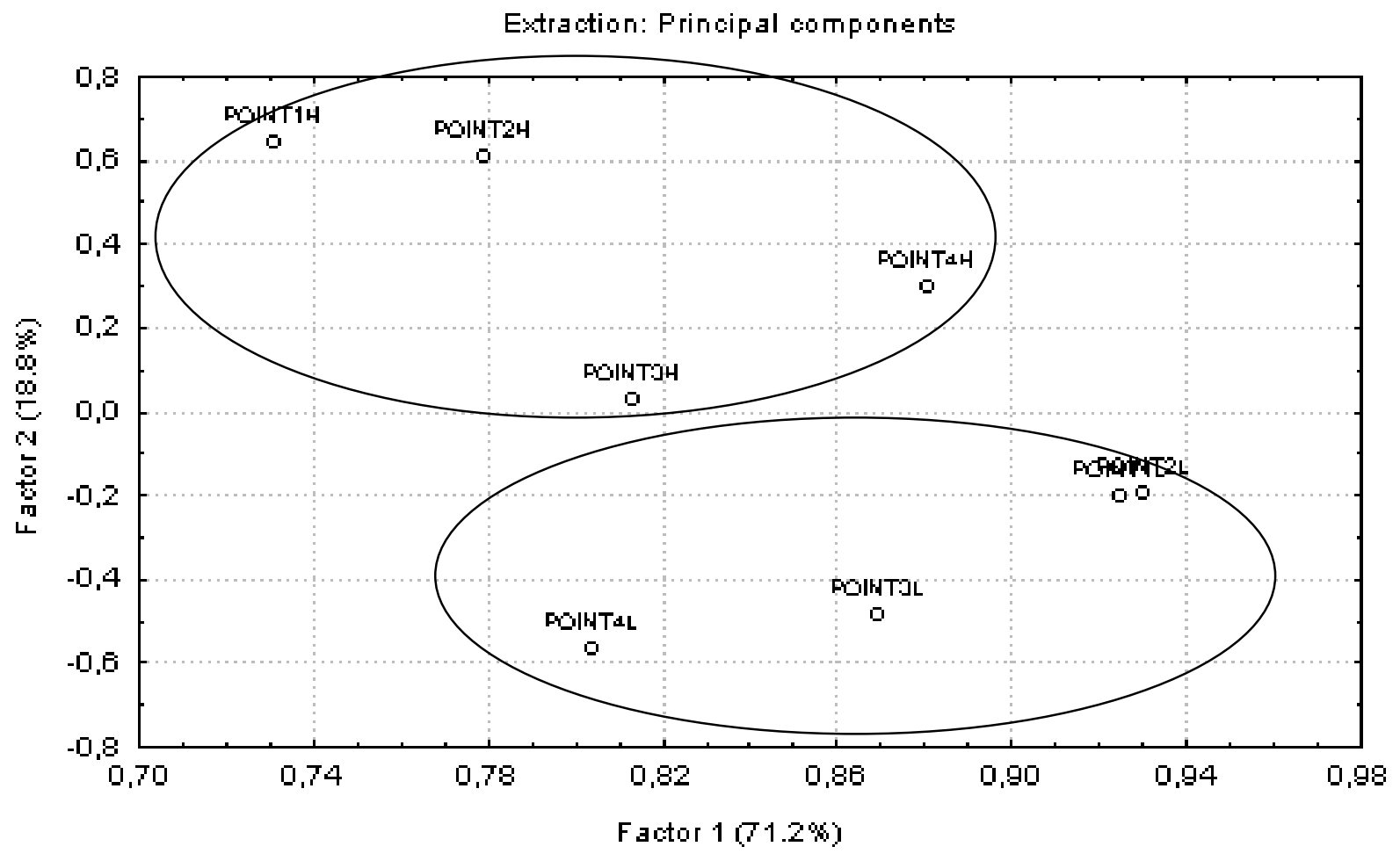

Figure 4 - Principal components analysis for the sampling spots in High (H) and low (L) temperatures for the fish comunity of the Fortaleza lagoon during November 1998 to October 1999.

\section{DISCUSSION}

The first important point to be considered in the study of a fish community is the establishment of a list of species. Since the Tramandaí river system presents a large variety of aquatic environments, it comprises a rich ichthyofauna. Malabarba and Isaia (1992) listed 73 freshwater fish species occurring on the system of Tramandaí River. From these species, $78 \%$ occur on the coastal plain where Fortaleza Lagoon is situated. In Rio Grande do Sul, Hartz (1997) listed a total of 35 species for Caconde Lagoon, an isolated freshwater coastal plain lagoon. Fialho (1998) listed 32 species for Custódias Lagoon, a coastal plain lagoon with estuarine influence and Bruschi Jr. (1998) listed 31 species for Marcelino and Peixoto lagoons. In all studied lagoons, most of the sampled species were typically freshwater. The most representative orders were Characiforms and Siluriforms, following the pattern proposed by Lowe-Mc Connell (1987) for South American ichthyofauna.
The Fortaleza Lagoon, as well as Caconde, Custódias, Marcelino and Peixoto lagoons also presented this tendency. The Characiforms seem to prevail in lenthic environments as found by Castro and Arcifa (1987) in São Paulo State dams, Sunaga and Verani (1991) in Vale do Rio Doce lakes in Minas Gerais State, Palmeira (1993) in the inundation plain of Miranda River (Mato Grosso State) and Veríssimo (1994) in isolated lagoons in Paraná State. Characiforms are also representative in estuarine environments, as has been found by Aguiaro and Caramaschi (1995) in three lagoons situated in Rio de Janeiro State. According to Lowe-McConnell (1975) in interconnected systems where the composition of species is more dynamic, constant species should not be expressive. This did not occur in the Fortaleza Lagoon, in the Custódias Lagoon (Fialho, 1998) and Marcelino and Peixoto lagoons (Bruschi, 1998) although belonging to a system of interconnected lagoons, these presented a large number of constant species. The same results were found by Lucena et al. (1994) and Tagliani (1994) 
who studied the ichtyofauna from Itapuã and small streams near Lagoa dos Patos (RS). Among the sampled species, only two, Centropomus sp (marine) and Lycengraulis grossidens (estuarine), were not characteristic freshwater species. Centropomus sp was considered accidental, with only one individual collected. Lycengraulis grossidens, although being characteristic of estuarine environments, was considered a constant species in Fortaleza Lagoon, probably due to the interconnectivity of the system. This same species occurred in Marcelino and Peixoto lagoons (Bruschi Jr., 1998) but was not sampled by Hartz (1997) in the Caconde Lagoon. The Fortaleza Lagoon showed less species compared to other coastal lagoons studied in the coastal plain of Rio Grande do Sul. However, the system appears to be more stable since most of the species are constant, and seam to reproduce in the lagoon despite the system's interconnectivity. The Fortaleza lagoon seams to offer favourable conditions for lenthic species that do not migrate. The results of the multivariate analysis suggest that the abundance of the fish community in the Fortaleza lagoon are more strongly influenced by temperature variation then by the differences between sampling points or species association. Most part of the species had a wide spatial-temporal distribution.

\section{ACKNOWLEDGMENTS}

The authors would like to thank CECLIMAR (Centro de Estudos Costeiros Limnológicos e Marinhos), Centro de Ecologia - UFRGS (Universidade Federal do Rio Grande do Sul) for providing laboratory facilities, Osvaldo and $\mathrm{Si}$ for helping in field work and Magda Yamada for helping in statistical analysis.

\section{RESUMO}

A Planície Costeira do Rio Grande do Sul é formada por uma série de corpos d'água, dispostos em sequiência ao longo da costa. A lagoa da Fortaleza pertence ao subsistema lagunar Tramandaí-Sul que é composto por lagoas, dispostas linearmente no sentido norte-sul. $\mathrm{O}$ do presente estudo teve como objetivo descrever alguns aspectos relacionados à composição da comunidade de peixes da Lagoa da Fortaleza. As amostragens foram realizadas, mensalmente, no período de novembro de 1998 a outubro de 1999. Os exemplares foram capturados em 4 pontos da lagoa previamente determinados e classificados em 5 ordens, 11 famílias e 22 espécies. As espécies Cyphocharax voga, Hyphessobrycon luetkenii, Oligosarcus jenynsii, Oligosarcus robustus e Loricariichthys anus mostraram-se as mais abundantes. Entre as espécies coletadas apenas duas não caracterizam espécies de água doce: Centropomus sp (marinha) and Lycengraulius grossidens (estuarina). A ictiofauna da lagoa caracterizou-se por uma predominância de espécies constantes.

\section{REFERENCES}

Aguiaro, T. and Caramaschi, E. P. (1995), Ichthyofauna composition of three coastal lagoons in the north state of Rio de Janeiro (Brazil). Arquivos de Biologia $e$ Tecnologia. 38 : (4), 1181-1189.

Böhlke, J. E.; Weitzman, S. H. and Menezes, N. A. (1978), Estado atual da sistemática de peixes de água doce na América do Sul. Acta Amazônica, 8, 657-677.

Bruschi Jr., W.; Salomoni, S. E.; Fermino, F. S.; Pedrozo, C. S.; Schwarzbold, A. and Peret, A. C. (1998), Aplicação de um índice de qualidade de águas para lagoas costeiras, RS, afetadas por despejos urbanos. Biociências, 6, 55-66.

Castro, R. M. C. and Arcifa, M. S. (1987), Comunidades de peixes de reservatórios no sul do Brasil Rev, Bras. Biol., 47 : (4), 493-500.

Dajoz, R. (1983), Ecologia Geral. São Paulo : Vozes. $472 \mathrm{pp}$.

Digby, P. G. N. and Kempton, R. A. (1987), Multivariate analysis of ecological communities. New York : Chapman and Hall. 205 pp.

Esteves, F. A.; Ishii, I. H. and Camargo, A. F. M. (1984), Pesquisas limnológicas em 14 lagoas do litoral do Estado do Rio de Janeiro. In: Restingas: Origem, Estrutura e Processo. Niterói : CEUFF. pp. 441-452.

Fausch, K. D.; Lyons, J.; Karr, J. R. and Angermeier, P. L. (1990), Fish communities as indicators of environmental degradation. Am. Fish. Soc. Symp., 8, 122-144.

Figueiredo, J. L. and Menezes, N. (1978), Manual de peixes marinhos do sudeste do Brasil. II Teleostei. São Paulo : Museu de Zoologia, USP. 110 pp.

Figueiredo, J. L. and Menezes, N. (1980), Manual de peixes marinhos do sudeste do Brasil. III Teleostei. São Paulo Museu de Zoologia, USP. 110 pp.

Jonhson, R. A. and Wichern, D.W. (1998), Applied Multivariate Statistical Analysis. $4^{\text {th }}$ ed. Prentice-Hall. 815 pp. 
Karr, J. R. (1991), Biological integrity a long neglected aspect of water resource management. Ecol Appl., 1, 66-87.

Lowe-McConnell, R. H. (1975), Fish communities in tropical freshwaters. New York : Longman Inc. 337 pp.

Lowe-McConnell, R. H. (1987), Ecological studies in tropical fish communities. Cambridge : Cambridge University Press. 382 pp.

Lucena, C. A. S; Jardim, A. S. and Vidal, E. S. (1994), Ocorrência, distribuição e abundância da fauna de peixes da praia de Itapuã, Viamão, Rio Grande do Sul, Brasil. Comun. Mus. Ciênc. PUCRS. Sér. Zool. 7, 3-27.

Malabarba, L. R. and Isaia, E. A. (1992), The freshwater fish fauna of the rio Tramandaí drainage, Rio Grande do Sul, with a discussion of its local origin. Comun. Mus. Ciênc. PUCRS. Sér. Zool. 5, 197-223.

Pielou, E. C. (1984), The interpretation of ecological data. New York Wieley.

Sunaga, T. and Verani, J. R. (1991), The fish communities of the lakes in Rio Doce valley, northeast Brazil.Verh. Internat. Verein. Limnol., 24, 2563-2566.

Tagliani, P. R. A. (1994), Ecologia da assembléia de peixes de três riachos da planície costeira do Rio Grande do Sul. Atlántica, 16, 55-68.

Yáñez-Arancibia, A. (1986), Ecologia de la zona costera: analisis de siete topicos. México : AGT. 200 pp.

Received: January 04, 2002; Revised: May 30, 2003; Accepted: May 12, 2004. 